НАУКОВИЙ ВІСНИК

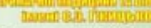

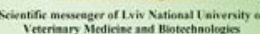

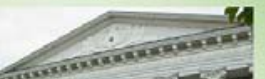

TIIIPY

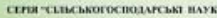
Toм 21 Nig 90

2019
Науковий вісник Львівського національного університету ветеринарної медицини та біотехнологій імені С.3. Гжицького. Серія: Сільськогосподарські науки

\author{
Scientific Messenger of Lviv National University
} of Veterinary Medicine and Biotechnologies.

Series: Agricultural sciences

UDC 636.2:636.082

\title{
Features of selection methods in the period of creation of Ukrainian red dairy breed
}

\author{
T.V. Pidpala, N.P. Shevchuk
}

Mykolayiv National Agrarian University, Mykolayiv, Ukraine

Article info

Received 24.01.2019

Received in revised form 27.02.2019

Accepted 28.02.2019

Mykolayiv National Agrarian University, Str. Georgiya Gongadze, 9, Mykolayiv, 54020, Ukraine.

Tel.: +38-099-502-69-82

E-mail:shev4uk.n@ukr.net
Pidpala, T.V., \& Shevchuk, N.P. (2019). Features of selection methods in the period of creation of Ukrainian red dairy breed. Scientific Messenger of Lviv National University of Veterinary Medicine and Biotechnologies. Series: Agricultural sciences, 21(90), 26-31. doi: 10.32718/nvlveta9005

Investigation of the selection methods, used during various stages of the creating the Ukrainian red dairy breed, has an actual significance in the evaluation of the methodology of the breed formation process. A comparative analysis found that the female ancestors of the studied cows according to milk yield significantly differed. With each subsequent stage, bulls-breeders, which were used in the breeding process, prevailed over female ancestors of the previous stage according to the milk productivity. The level of maternity benefit of the parents of the second and third stages was higher than that of the parents of the first stage mothers. However, for fatty milk, the parents of stage I parents had a superiority, compared with the second and third stages. While analyzing the milk yield of mothers of cows, it was found a certain pattern. In particular, the increase in milk in the next stages of the breeding of Ukrainian red dairy breed. According to the productivity of cows-primates, derived from different selection methods, determined by the level of support of female ancestors, the effectiveness of the use of highly heterogeneous selection is established. The difference in comparison with the homogeneous selection for the second and third stages was $462 \mathrm{~kg}(P>0.999)$ and $235 \mathrm{~kg}$ of milk, respectively. As for the first stage of breeding of Ukrainian red dairy breed, the best results were obtained from the use of moderately heterogeneous selection. Its efficiency is confirmed by the highest milk yield of $359 \mathrm{~kg}(P>0.95)$ of milk compared with homogeneous selection. There was a tendency to increase the fat content in milk of animals in the I, II and III stages of the breeding process in a highly heterogeneous selection in comparison with homogeneous selection, the difference was accordingly $0.04 \%$, $0.05 \%$ and $0.03 \%$. It should be noted that in the second stage, heterogeneous selection was effective. Along with the abovementioned, there is a general tendency of reduction of fatty milk production in III stage compared to I and II stages. This is explained by the inclusion in the program of the breeding process of the Ukrainian red dairy breed using the Holstein breeder bulls. Based on the analysis of the data obtained, we have a convincing confirmation of the effectiveness of a highly heterogeneous selection. In the first and second stages of breeding, the prevail of milk fat was $15.4 \mathrm{~kg}(P>0.99)$ and $12.9 \mathrm{~kg}(P>0.95)$ compared to homogeneous selection. Thus, it is logical to increase the level of milk productivity in the studied cows from the first to the third stage of the withdrawal of Ukrainian red dairy breeds with the advantage of using highly heterogeneous selection.

Key words: Ukrainian red milk breed, breeding process, homogeneous selection, heterogeneous selection, sign, milk productivity.

\section{Особливості методів підбору в період створення української червоної молочної породи}

\author{
Т.В. Підпала, Н.П. Шевчук
}

Миколаївський національний аграрний університет, м. Миколаїв, Украӥна 
Дослідження методів підбору, застосовуваних протягом різних етапів виведення української червоної молочної породи має актуальне значення в очіниі методології породоутворювального процесу. Порівняльним аналізом встановлено, щзо жіночі предки досліджуваних корів за молочною продуктивністю значно відрізнялися між собою. 3 кожним наступним етапом бугаї-плідники, які використовувалися у породотворному прочесі переважали за молочною продуктивністю жіночих предків попереднього етапу. Рівень надою матерів батьків II і III етапу був вищим ніж у матерів батьків I етапу. Проте за жирномолочністю перевагу мали матері батьків I етапу, різниця порівняно з II і III етапами. Аналізуючи молочну продуктивність матерів корів, також виявили певну закономірність, зокрема підвищення молочності у наступних етапах виведення української червоної молочної породи. За даними продуктивності корів-первісток, отриманих від різних методів підбору, щцо визначені за рівнем надою жіночих предків, встановлено ефективність використання високо гетерогенного підбору. Різниия порівняно з гомогенним підбором за II і ІІІ етапи становила 462 кг (P> 0,999)і 235 кг молока, відповідно. Щодо I етапу виведення украӥнської червоної молочної породи, то кращі результати було отримано від застосування помірно гетерогенного підбору. Його ефективність підтверджується вищим надоєм на 359 кг (P> 0,95) молока порівняно з гомогенним підбором. Встановлено тенденцію щзодо підвищення жирномолочності тварин y I, II і III етапах виведення породи за високо гетерогенного підбору порівняно з гомогенним підбором, різниия відповідно становила 0,04\%, 0,05\% і 0,03\%. Варто зазначити, шо у II етапі ефективним був і гетерогенний підбір. Поряд із зазначеним спостерігається загальна тендениія зниження жирномолочності у III етапі порівняно з I і II етапами. Це пояснюється включенням до програми виведення украӥнської червоної молочної породи використання бугаїв-плідників голштинської породи. На підставі аналізу отриманих даних маємо переконливе підтвердження щзодо ефективності високо гетерогенного підбору. У I та II етапах виведення породи перевага за кількістю молочного жиру становила 15,4 кг (P> 0,99) та 12,9 кг (P>0,95) порівняно з гомогенним підбором. Отже, закономірним є підвищення рівня молочної продуктивності у досліджуваних корів з I до III етапу виведення української червоної молочної породи з перевагою за використання високо гетерогенного підбору

Ключові слова: украӥнська червона молочна порода, породоутворювальний прочес, гомогенний підбір, гетерогенний підбір, ознака, молочна продуктивність.

\section{Ветуп}

Породоутворювальний процес у молочному скотарстві триває постійно, оскільки вимоги до рівня розвитку господарсько корисних ознак у тварин змінюються залежно від потреб суспільства. Однак визначальними критеріями завжди були високий рівень молочної продуктивності корів та добра їхня відтворювальна здатність, що $є$ основними господарськи корисними ознаками, які входять до складу комплексного індексу селекційної цінності тварин у країнах 3 розвиненим молочним скотарством (Caraviello et al., 2006; Van Raden et al., 2011).

3 використанням різних селекційно-генетичних прийомів відбувається удосконалення існуючих та виведення нових порід. Серед них значна роль належить племінному підбору, завдяки якому створюються бажанні поєднання селекційних ознак у тварин наступних поколінь (VandeHaar et al., 2016; Yudin et al., 2016; Hutchison et al., 2017; Fyl' et al., 2018).

При виведенні нових порід переважно використовувався гетерогенний метод підбору. Його результативність залежала від багатьох факторів, які певним чином зумовлювали і ефективність створення нових порід, типів, ліній. Тому дослідження методів підбору що застосовували протягом різних етапів виведення української червоної молочної породи (Shevchuk, 2017) має актуальне значення в оцінці методології породоутворювального процесу.

Питанням використання методів підбору для поліпшення існуючих та створення нових порід завжди цікавилися вчені, селекціонери-практики. Так, гетерогенність підбору сприяє отриманню ремонтного молодняку бажаної якості й при цьому можуть проявлятися певні відмінності від одного або обидвох батьків (Levina, 2005; Pelekhatyy \& Kucher, 2012; Pelekhatyy et al., 2012). М. Пелехатий та Д. Кучер (Pelekhatyy \& Kucher, 2014) зазначають, що при підборі бугаїв до корів варто враховувати рівень їх гетерогенності (за найвищим надоєм матерів батьків) стосовно до надою матерів корів, на яких будуть використовуватися дані плідники, тому що від цього залежить майбутній результат. Параметрами бажаного типу характеризуються корови-первістки, які отриманні із застосуванням високогетерогенного та гомогенного поліпшувального підбору за селекційними індексами. Тварини, що отримані від гомогенного поліпшувального типу підбору батьків, мали надій за 305 днів лактації 5459,9 кг молока з вмістом жиру 3,99\% і білка 3,07\% (Kucher, 2018).

Узагальненими результатами племінного підбору у відкритій популяції молочної худоби було доведено, що найефективнішими типами є гетерогенний та високогетерогенний підбори. Рівень продуктивності корів, отриманих від такого підбору, становив за надоєм 5132-5150 кг, кількістю молочного жиру 203,2204,7 кг, молочного білка 158,6-160,1 кг, сумарної продукції молочного жиру і білка 361,8-364,8 кг при високо достовірній різниці порівняно 3 коровамипервістками, отриманими від помірно гетерогенного підбору (Pelekhatyy et al., 2012).

Дослідженнями C.I. Гнатюк, M.A. Гнатюк (Gnatyuk \& Gnatyuk, 2014) встановлено, що в стадах української червоної молочної породи 3 рівнем продуктивності 3000-5000 кг молока за лактацію кращим $\epsilon$ високо гетерогенний підбір для тварин жирномолочного внутрішньопородного типу, а гетерогенний для тварин голштинізованого типу.

Є повідомлення, що при виборі варіанту гетерогенного підбору слід враховувати рівень продуктивності материнського стада. Для корів з надоєм 30006000 кг молока за кращу лактацію оптимальним є гетерогенний підбір, а для тварин 3 надоєм понад 6000 кг молока - помірно гетерогенний підбір. Поряд 3 цим зазначається, що використання гомогенного підбору на сучасному етапі селекції української червоної молочної породи є не доцільним (Gnatyuk et al., 2014).

Зважаючи на можливості підбору та наявність суперечливості між результатами, необхідним є продовження дослідження гетерогенного підбору як при створенні, так і на сучасному етапі удосконалення 
новостворених порід молочної худоби, що відбувається за принципом відкритої популяції.

Мета досліджень. Оцінити результативність методів підбору, що використовувалися на різних етапах створення української червоної молочної породи великої рогатої худоби.

\section{Матеріал і методи досліджень}

Для виконання дослідження використали дані племінного і зоотехнічного обліку стада великої рогатої худоби української червоної молочної породи племзаводу ПОК “Зоря” Херсонської області за 1970 1999 роки (період виведення української червоної молочної породи). Даний племінний завод був одним iз великих базових господарств, де здійснювалися породоутворювальні процеси в популяції червоної степової худоби. Зазначений період умовно розподілили на декілька етапів, протягом яких відбувалося створення української червоної молочної породи, зокрема: I етап - 1965-1975 роки, II етап - 19761985 роки і III етап - 1985-1995 роки. Для ретроспективного аналізу було відібрано 637 тварин, в тому числі за етапами: $\mathrm{I}-\mathrm{n}=248$ корів, II $-\mathrm{n}=255$ корів і III $-\mathrm{n}=134$ корови.

Матеріалом для визначення гомогенності чи гетерогенності підбору стали рівень надою та жирномолочності жіночих предків досліджуваних тварин. За різницею, яка виражена середнім квадратичним відхиленням з відповідним інтервалом між показниками за найвищу лактацію матерів батьків (МБ) та матерями корів (МК), підбір розподілили на: гомогенний -
$0,4 \sigma$ і менше; помірно гетерогенний $-0,5-1,4 \sigma$; гетерогенний $-1,5-2,4 \sigma$ і високо гетерогенний $-2,5 \sigma \mathrm{i}$ більше. Результативність різних методів підбору визначали за молочною продуктивність корів за першу лактацію, що продукували в різні періоди виведення української червоної молочної породи великої рогатої худоби.

Для дослідження використовували методи ретроспективного аналізу і варіаційної статистки (Plohinskij, 1969; Pidpala, 2012). Матеріали досліджень опрацьовані 3 використанням програмного забезпечення Microsoft Excel.

\section{Результати та їх обговорення}

Порівняльним аналізом встановлено, що жіночі предки досліджуваних корів за молочною продуктивністю значно відрізнялися між собою (табл. 1).

3 кожним наступним етапом бугаї-плідники, які використовувалися у породотворному процесі, переважали за молочною продуктивністю жіночих предків попереднього етапу. Рівень надою матерів батьків II і III етапу був вищим на 994 кг (Р > 0,999) і 2882 кг молока (P > 0,999), ніж у матерів батьків I етапу.

Проте за жирномолочністю перевагу мали матері батьків I етапу різниця порівняно 3 II і III етапами відповідно становила 0,09\% і 0,29\% (Р> 0,999). Разом 3 тим за кількістю молочного жиру вищими показниками характеризувалися матері батьків II і III етапів. Їх значення були, відповідно, більшими на 39,5 кг $(\mathrm{P}>0,999)$ і 104,6 кг $(\mathrm{P}>0,999)$, ніж у матерів батьків І етапу.

\section{Таблиця 1}

Характеристика молочної продуктивності жіночих предків досліджуваних корів

\begin{tabular}{|c|c|c|c|c|c|}
\hline \multirow{2}{*}{$\begin{array}{c}\text { Етап виведення } \\
\text { породи }\end{array}$} & \multirow{2}{*}{$\begin{array}{c}\text { Предки } \\
\text { корів }\end{array}$} & \multirow{2}{*}{ Ознака } & \multicolumn{3}{|c|}{ Параметр } \\
\hline & & & $\bar{X} \pm S x$ & $\sigma$ & $C v, \%$ \\
\hline \multirow{6}{*}{$\begin{array}{l}\text { I етап, } \\
\mathrm{n}=248\end{array}$} & \multirow{3}{*}{$\begin{array}{l}\text { Матері } \\
\text { батьків }\end{array}$} & Надій за 305 днів кращої лактації, кг & $6520 \pm 84,6$ & 1332,0 & 20,4 \\
\hline & & Вміст жиру в молоці, \% & $4,50 \pm 0,049 * * *$ & 0,77 & 17,1 \\
\hline & & Кількість молочного жиру, кг & $291,3 \pm 3,82$ & 60,2 & 20,7 \\
\hline & \multirow{3}{*}{$\begin{array}{c}\text { Матері } \\
\text { корів }\end{array}$} & Надій за 305 днів кращої лактації, кг & $4855 \pm 44,6$ & 703,0 & 14,5 \\
\hline & & Вміст жиру в молоці, \% & $3,90 \pm 0,016$ & 0,26 & 6,6 \\
\hline & & Кількість молочного жиру, кг & $188,9 \pm 1,87$ & 29,5 & 15,6 \\
\hline \multirow{6}{*}{$\begin{array}{l}\text { II етап, } \\
\mathrm{n}=255\end{array}$} & \multirow{3}{*}{$\begin{array}{l}\text { Матері } \\
\text { батьків }\end{array}$} & Надій за 305 днів кращої лактації, кг & $7514 \pm 93,1^{* * *}$ & 1487,0 & 19,8 \\
\hline & & Вміст жиру в молоці, \% & $4,41 \pm 0,030$ & 0,48 & 10,9 \\
\hline & & Кількість молочного жиру, кг & $330,8 \pm 4,36^{* * *}$ & 69,6 & 21,0 \\
\hline & \multirow{3}{*}{$\begin{array}{l}\text { Матері } \\
\text { корів }\end{array}$} & Надій за 305 днів кращої лактації, кг & $5668 \pm 48,4 * * *$ & 772,7 & 13,6 \\
\hline & & Вміст жиру в молоці, \% & $4,02 \pm 0,016^{* * *}$ & 0,26 & 6,4 \\
\hline & & Кількість молочного жиру, кг & $235,4 \pm 8,23 * * *$ & 131,5 & 55,9 \\
\hline \multirow{6}{*}{$\begin{array}{l}\text { III етап } \\
\mathrm{N}=134\end{array}$} & \multirow{3}{*}{$\begin{array}{l}\text { Матері } \\
\text { батьків }\end{array}$} & Надій за 305 днів кращої лактації, кг & $9402 \pm 97,0^{* * *}$ & 1123,0 & 11,9 \\
\hline & & Вміст жиру в молоці, \% & $4,21 \pm 0,026$ & 0,30 & 7,1 \\
\hline & & Кількість молочного жиру, кг & $395,9 \pm 4,70^{* * *}$ & 54,5 & 13,8 \\
\hline & \multirow{3}{*}{$\begin{array}{c}\text { Матері } \\
\text { корів }\end{array}$} & Надій за 305 днів кращої лактації, кг & $5647 \pm 102,7 * * *$ & 1189,0 & 21,0 \\
\hline & & Вміст жиру в молоці, \% & $3,93 \pm 0,012$ & 0,13 & 3,4 \\
\hline & & Кількість молочного жиру, кг & $221,7 \pm 3,91 * * *$ & 45,2 & 20,4 \\
\hline
\end{tabular}

Примітка: ${ }^{* * *}$ - P > 0,999 у порівнянні II і III етапи з I етапом

Аналізуючи молочну продуктивність матерів корів, також виявили певну закономірність, зокрема підвищення молочності у наступних етапах виведення української червоної молочної породи. Якщо в I етапі рівень надою матерів корів становив 4855 кг молока, то у II і III етапах породоутворювального процесу спостерігається його збільшення на 813 кг (Р > 0,999) і 792 кг (Р > 0,999) молока відповідно. 
Поряд 3 цим встановлено зміну жирномолочності у матерів корів. Так, вміст жиру в молоці вищий у матерів корів II етапу на $0,12 \%(P>0,999)$ і III етапу на $0,03 \%$ порівняно з матерями корів I етапу. За кількістю молочного жиру виявлено перевагу матерів корів II і III етапів, різниця порівняно 3 матерями корів I етапу відповідно становила 46,5 кг $(\mathrm{P}>0,999)$ i 32,8 кг $(\mathrm{P}>0,999)$.

Отже, закономірним є підвищення рівня молочної продуктивності жіночих предків досліджуваних корів з I до III етапу виведення української червоної молочної породи.

Зважаючи на наявність відмінностей за рівнем продуктивності матерів батьків і матерів корів як між етапами виведення породи, так і у розрізі кожного етапу оцінили результативність гетерогенного підбоpy.
Дані продуктивності корів-первісток, отриманих відрізних методів підбору, що визначені за рівнем надою жіночих предків, наведено в таблиці 2.

Встановлено, що найбільш результативним за молочністю тварин $є$ високо гетерогенний підбір. Серед досліджуваного поголів'я корів I етапу від такого підбору отримано 46,4\% тварин, а II і III етапів 45,1\% і 94,1\% відповідно.

Порівняльним аналізом визначено перевагу за рівнем надою у тварин, що отриманні в результаті високо гетерогенного підбору. Різниця у порівнянні з гомогенним підбором за II і III етапи становила 462 кг $(\mathrm{P}>0,999)$ і 235 кг молока відповідно.

Щодо I етапу виведення української червоної молочної породи, то кращі результати було отримано від застосування помірно гетерогенного підбору. Його ефективність підтверджується вищим надоєм на 359 кг $(\mathrm{P}>0,95)$ молока порівняно 3 гомогенним підбором.

\section{Таблиця 2}

Оцінка методів підбору за молочною продуктивністю корів-первісток у різні етапи виведення української червоної молочної породи, $\bar{X} \pm S x$ (рівень гетерогенності за надоєм жіночих предків)

\begin{tabular}{|c|c|c|c|c|}
\hline \multirow{2}{*}{ Ознака } & \multicolumn{4}{|c|}{ Метод підбору } \\
\hline & гомогенний & помірно гетерогенний & гетерогенний & високо гетерогенний \\
\hline \multicolumn{5}{|c|}{ І етап } \\
\hline $\mathrm{n} / \%$ & $35 / 14,1$ & $41 / 16,5$ & $57 / 23,0$ & $115 / 46,4$ \\
\hline Надій за 305 днів лактації, кг & $3376 \pm 131,6$ & $3735 \pm 88,9 *$ & $3558 \pm 79,1$ & $3647 \pm 62,2$ \\
\hline Вміст жиру в молоці, \% & $4,03 \pm 0,054$ & $3,87 \pm 0,052 *$ & $4,03 \pm 0,036$ & $3,93 \pm 0,028$ \\
\hline Кількість молочного жиру, кг & $135,3 \pm 5,38$ & $143,9 \pm 3,72$ & $144,1 \pm 3,54$ & $143,6 \pm 2,63$ \\
\hline \multicolumn{5}{|c|}{ II етап } \\
\hline $\mathrm{n} / \%$ & $40 / 15,7$ & $60 / 23,5$ & $40 / 15,7$ & $115 / 45,1$ \\
\hline Надій за 305 днів лактації, кг & $4020 \pm 95,9$ & $4172 \pm 84,0$ & $4163 \pm 107,9$ & $4482 \pm 78,7 * * *$ \\
\hline Вміст жиру в молоці, \% & $4,09 \pm 0,059$ & $4,06 \pm 0,037$ & $4,03 \pm 0,034$ & $3,98 \pm 0,024$ \\
\hline Кількість молочного жиру, кг & $164,5 \pm 4,36$ & $167,9 \pm 3,31$ & $168,6 \pm 4,12$ & $178,0 \pm 3,06^{*}$ \\
\hline \multicolumn{5}{|c|}{ III етап } \\
\hline $\mathrm{n} / \%$ & $3 / 2,2$ & $2 / 1,5$ & $3 / 2,2$ & $126 / 94,1$ \\
\hline Надій за 305 днів лактації, кг & $4221 \pm 614,5$ & $4285 \pm 224,5$ & $4577 \pm 164,2$ & $4456 \pm 63,4$ \\
\hline Вміст жиру в молоці, \% & $3,96 \pm 0,084$ & $3,91 \pm 0,020$ & $3,84 \pm 0,062$ & $3,86 \pm 0,011$ \\
\hline Кількість молочного жиру, кг & $199,4 \pm 55,38$ & $167,8 \pm 9,60$ & $178,5 \pm 6,24$ & $172,4 \pm 2,36$ \\
\hline
\end{tabular}

Примітки: *- $\mathrm{P}>0,95 ; * * *-\mathrm{P}>0,999$ у порівнянні з гомогенним підбором

Дослідженнями C.I. Гнатюк, M.A. Гнатюк (Gnatyuk \& Gnatyuk, 2014) на прикладі внутрішньопородних типів української червоної молочної породи встановлено закономірне підвищення рівня надою у корів зі збільшенням ступеня гетерогенності. Ними ж відмічено наявність вірогідної різниці між високо гетерогенним та гомогенним підбором, яка за надоєм у первісток становила 504 кг молока.

Гетерогенність підбору також визначали за жирномолочністю жіночих предків (табл. 3).

Оскільки при виведенні української червоної молочної породи на перших етапах для схрещування використовували бугаїв-плідників англерської породи, тим самим досягали підвищення вмісту жиру в молоці у нащадків. Згідно з методикою досліджень було виділено такий підбір: гомогенний, помірно гетерогенний, гетерогенний і високо гетерогенний. У результаті такого розподілення встановлено, що в різні етапи виведення породи отримано від гомоген- ного 30,2-37,5\% тварин і 27,9-35,8\% - від високо гетерогенного підбору.

Встановлено тенденцію щодо підвищення жирномолочності у тварин у I, II і III етапах виведення породи за високо гетерогенного підбору порівняно 3 гомогенним підбором, різниця відповідно становила 0,04\%, 0,05\% і 0,03\%. Варто відмітити, що у II етапі ефективним був і гетерогенний підбір. Поряд із зазначеним спостерігається загальна тенденція зниження жирномолочності у III етапі порівняно з I і II етапами. Це пояснюється включенням до програми виведення української червоної молочної породи використання бугаїв-плідників голштинської породи.

Іншими дослідниками (Gnatyuk \& Gnatyuk, 2014) при вивченні рівня жирномолочності тварин за першу, третю і найкращу лактації не встановлено будьякої закономірності прояву даної ознаки від ступеня гетерозиготності при підборі. 
Таблиця 3

Оцінка методів підбору за молочною продуктивністю корів-первісток у різні етапи виведення української червоної молочної породи, $\bar{X} \pm S x$ (рівень гетерогенності за жирномолочністю жіночих предків)

\begin{tabular}{|c|c|c|c|c|}
\hline \multirow{2}{*}{ Ознака } & \multicolumn{4}{|c|}{ Метод підбору } \\
\hline & гомогенний & помірно гетерогенний & гетерогенний & високо гетерогенний \\
\hline \multicolumn{5}{|c|}{ I етап } \\
\hline $\mathrm{n} / \%$ & $93 / 37,5$ & $57 / 23,0$ & $20 / 8,1$ & $78 / 31,4$ \\
\hline Надій за 305 днів лактації, кг & $3559 \pm 67,6$ & $3538 \pm 102,0$ & $3647 \pm 127,7$ & $3691 \pm 67,5$ \\
\hline Вміст жиру в молоці, \% & $3,98 \pm 0,034$ & $3,87 \pm 0,034^{*}$ & $3,88 \pm 0,058$ & $4,02 \pm 0,036$ \\
\hline Кількість молочного жиру, кг & $141,8 \pm 2,96$ & $136,3 \pm 3,93$ & $142,1 \pm 5,19$ & $148,3 \pm 2,90$ \\
\hline \multicolumn{5}{|c|}{ II етап } \\
\hline $\mathrm{n} / \%$ & $77 / 30,2$ & $72 / 28,2$ & $35 / 13,7$ & $71 / 27,9$ \\
\hline Надій за 305 днів лактації, кг & $4499 \pm 89,3$ & $4258 \pm 96,9$ & $4121 \pm 137,1^{*}$ & $4166 \pm 70,7 * *$ \\
\hline Вміст жиру в молоці, \% & $4,03 \pm 0,031$ & $3,94 \pm 0,021 *$ & $4,06 \pm 0,047$ & $4,08 \pm 0,042$ \\
\hline Кількість молочного жиру, кг & $179,4 \pm 3,29$ & $167,7 \pm 3,74^{*}$ & $167,7 \pm 5,46$ & $170,6 \pm 3,13$ \\
\hline \multicolumn{5}{|c|}{ III етап } \\
\hline $\mathrm{n} / \%$ & $45 / 33,6$ & $19 / 14,2$ & $22 / 16,4$ & $48 / 35,8$ \\
\hline Надій за 305 днів лактації, кг & $4387 \pm 103,8$ & $4451 \pm 164,7$ & $4685 \pm 118,5$ & $4402 \pm 110,4$ \\
\hline Вміст жиру в молоці, \% & $3,85 \pm 0,020$ & $3,88 \pm 0,021$ & $3,84 \pm 0,019$ & $3,88 \pm 0,020$ \\
\hline Кількість молочного жиру, кг & $171,4 \pm 5,08$ & $172,0 \pm 6,22$ & $179,6 \pm 4,12$ & $172,2 \pm 3,96$ \\
\hline
\end{tabular}

Примітки: ${ }_{-}-\mathrm{P}>0,95 ; *_{-} \mathrm{P}>0,99$ у порівнянні з гомогенним підбором

Зважаючи на те, що узагальненим показником продуктивності є кількість молочного жиру, то для оцінювання методів підбору використали дану ознаку за найкращу лактацію жіночих предків (МБ і МК) досліджуваних корів. Принцип визначення гомогенності та гетерогенності аналогічний як і за надоєм. За такого розподілу також тварини відносяться до гомогенного та різного ступеня гетерогенного підбору (табл. 4).
Найбільшу частку становить високо гетерогенний підбір, зокрема у I та II етапах таких тварин 68,9\% та $52,1 \%$, відповідно, а у III етапі - 96,3\%.

На підставі аналізу отриманих даних маємо переконливе підтвердження щодо ефективності високо гетерогенного підбору. У I та II етапи виведення породи перевага за кількістю молочного жиру становила 15,4 кг $(\mathrm{P}>0,99)$ та 12,9 кг $(\mathrm{P}>0,95)$ порівняно з гомогенним підбором.

\section{Таблиця 4}

Оцінка методів підбору за молочною продуктивністю корів-первісток у різні етапи виведення української червоної молочної породи, $\bar{X} \pm S x$ (рівень гетерогенності за кількістю молочного жиру жіночих предків)

\begin{tabular}{|c|c|c|c|c|}
\hline \multirow{2}{*}{ Ознака } & \multicolumn{4}{|c|}{ Метод підбору } \\
\hline & гомогенний & помірно гетерогенний & гетерогенний & високо гетерогенний \\
\hline \multicolumn{5}{|c|}{ I етап } \\
\hline $\mathrm{n} / \%$ & $22 / 8,9$ & $25 / 10,1$ & $30 / 12,1$ & $171 / 68,9$ \\
\hline Надій за 305 днів лактації, кг & $3313 \pm 153,4$ & $3449 \pm 156,9$ & $3667 \pm 116,1$ & $3651 \pm 47,9^{*}$ \\
\hline Вміст жиру в молоці, \% & $3,97 \pm 0,067$ & $3,98 \pm 0,058$ & $3,88 \pm 0,049$ & $3,97 \pm 0,024$ \\
\hline Кількість молочного жиру, кг & $129,6 \pm 5,42$ & $137,8 \pm 6,76$ & $142,6 \pm 4,69$ & $145,0 \pm 2,07 * *$ \\
\hline \multicolumn{5}{|c|}{ II етап } \\
\hline $\mathrm{n} / \%$ & $31 / 12,2$ & $37 / 14,5$ & $54 / 21,2$ & $133 / 52,1$ \\
\hline Надій за 305 днів лактації, кг & $4030 \pm 108,6$ & $4110 \pm 104,5$ & $4259 \pm 97,3$ & $4406 \pm 71,4^{* *}$ \\
\hline Вміст жиру в молоці, \% & $4,08 \pm 0,062$ & $3,99 \pm 0,043$ & $4,02 \pm 0,035$ & $4,02 \pm 0,024$ \\
\hline Кількість молочного жиру, кг & $164,2 \pm 4,38$ & $160,9 \pm 3,80$ & $171,6 \pm 3,94$ & $177,1 \pm 2,76^{*}$ \\
\hline \multicolumn{5}{|c|}{ III етап } \\
\hline $\mathrm{n} / \%$ & $5 / 3,7$ & 0 & 0 & $129 / 96,3$ \\
\hline Надій за 305 днів лактації, кг & $4247 \pm 344,4$ & 0 & 0 & $4459 \pm 62,0$ \\
\hline Вміст жиру в молоці, \% & $3,94 \pm 0,048$ & 0 & 0 & $3,86 \pm 0,011$ \\
\hline Кількість молочного жиру, кг & $186,8 \pm 31,45$ & 0 & 0 & $172,6 \pm 2,31$ \\
\hline
\end{tabular}

Примітки: *- $\mathrm{P}>0,95 ; *_{-} \mathrm{P}>0,99$ у порівнянні з гомогенним підбором

\section{Висновки}

Встановлено, що закономірним є підвищення рівня молочної продуктивності жіночих предків досліджуваних корів з I до III етапу виведення української червоної молочної породи. Порівняльним аналізом визначено перевагу за рівнем надою у тварин, що отримані в результаті високо гетерогенного підбору.
Виявлено тенденцію щодо підвищення жирномолочності у тварин у I, II і III етапах виведення породи за високо гетерогенного підбору порівняно з гомогенним підбором.

Перспективи подальших досліджень. На перспективу передбачається дослідити ефективність використання спорідненого розведення в різні етапи створення української червоної молочної породи. 


\section{References}

Caraviello, D.Z., Weigel, K.A., Fricke, P.M., Wiltbank, M.C., Florent, M.J., Cook, N.B., Nordlund, K.V., Zwald, N.R., \& Rawson, C. L. (2006). Survey of Management Practices on Reproductive Performance of Dairy Cattle on Large US Commercial Farms. J. Dairy Sci., 89, 4723-4735. doi: 10.3168/jds.S00220302(06)72522-X.

Fyl', S.I., Fedorovych, Je.I., Bodnar, P.V. (2018). Vidtvorna zdatnist' koriv ta i'h nashhadkiv riznyh pokolin'. Naukovyj visnyk L'vivskogo nacional'nogo universytetu veterynarnoi' medycyny ta biotehnologii' im. S.Z. Gzhyc'kogo, 20(89), 114-121. doi: 10.32718/nvlvet8921 (in Ukrainian).

Gnatyuk, S.I., \& Gnatyuk, M.A. (2014). Geterogennij pidbir ta jogo vply`v na molochnu produkty`vnist` tvary`n rizny`x vnutrishn`oporodny’x ty`piv ukrayins`koyi chervonoyi molochnoyi porody`. Visnyk Sumskoho natsionalnoho ahrarnoho universytetu, naukovo-metodychnyi zhurnal. Seriia "Tvarynnytstvo", 2/2(25), 48-51. http://nbuv.gov.ua/UJRN/Vsna_tvar_2014_2\%282\%2 $9 \_12$ (in Ukrainian).

Gnatyuk, S.I., Kovalenko, V.I., \& Gnatyuk, M.A. (2014). Osobly`vosti intensy`vnosti rostu remontnogo molodnyaku pry` rizny'x variantax pleminnogo pidboru. Visnyk Sumskoho natsionalnoho ahrarnoho universytetu, naukovo-metodychnyi zhurnal. Seriia: Tvarynnytstvo, 2/1(24), 30-35. http://nbuv.gov.ua/ UJRN/Vsna tvar $2014 \quad 2 \% 281 \% 29 \quad 7$ Ukrainian).

Hutchison, J.L., VanRaden, P.M., Null, D.J., Cole, J.B., \& Bickhart, D.M. (2017). Genomicevaluation of age at first calving. Journal of Dairy Science, 100(8), 6853-6861. doi: 10.3168/jds.2016-12060.

Kucher, D.M. (2018). Zastosuvannya cilenapravlenogo pidboru zaselekcijny'my` indeksamy` bat'kivs`ky`x par u molochnomu skotarstvi. Visnyk Sumskoho natsionalnoho ahrarnoho universytetu, naukovometodychnyi zhurnal. Seriia: Tvarynnytstvo, 2(34), 4549. http://nbuv.gov.ua/UJRN/Vsna_tvar_2018_2_10 (in Ukrainian).

Levina, G.N. (2005). Ispol'zovanie geterogennogo podbora po urovnju udoja v selekcii vysokoproduktivnyh molochnyh stad. Agrarnaja nauka, 5, 29-30 (in Russian).
Pelekhatyy, M., \& Kucher, D. (2012). Gospodars`kokory`snioznaky` koriv-pervistok ukrayins`koyi chorno-ryaboyi molochnoyi pry` riznomu rivni geterogennogo pidboru. Visnyk Sumskoho natsionalnoho ahrarnoho universytetu, naukovometodychnyi zhurnal. Seriia: Tvarynnytstvo, 7, 59-67 (in Ukrainian).

Pelekhatyy, M., \& Kucher, D. (2014). Pleminny’j pidbir dlya vy`sokoprodukty`vnogo zavods`kogo stada molochnoyi xudoby`. Tvary`nny`cztvo Ukrayiny`, 34, 19-24. http://nbuv.gov.ua/UJRN/TvUkr_2014_34_8 (in Ukrainian).

Pelekhatyy, M.S., Piddubna, L.M., \& Kucher, D.M. (2012). Pleminny`j pidbir u vidkry`tij populyaciyi molochnoyi xudoby`. Texnologiya vy`robny`cztva i pererobky' produkciyi tvary`nny`cztva: zb. nauk. pracz' Bilocerkivs`kogo derzhavnogo agrarnogo universy`tetu. Bila Cerkva, 7(90), 94-98 (in Ukrainian).

Pidpala, T.V. (2012). Selektsiia molochnoik hudoby i svynei. Mykolaiv: MNAU. http://dspace.mnau. edu.ua:8080/jspui/handle/123456789/2577 (in Ukrainian).

Plohinskij, N.A. (1969). Rukovodstvo po biometrii dlja zootehnikov. M.: Kolos (in Russian).

Shevchuk, N.P. (2017). Genezys ukrai'ns'koi' chervonoi' molochnoi' porody. Naukovyj visnyk L'vivskogo nacional'nogo universytetu veterynarnoi' medycyny ta biotehnologii' im. S.Z. Gzhyc'kogo, 19(74), 203-207. doi: 10.15421/nvlvet7444 (in Ukrainian).

Van Raden, P.M., Olson, K.M., Null, D.J., Hutchison, J.L. (2011). Harmful recessive effects on fertility detected by absence of homozygous haplo types. J. Dairy Sci., 94(12), 6153-6161. doi: 10.3168/jds.20114624.

VandeHaar, M.J., Armentano, L.E., Weigel, K., Spurlock, D.M., Tempelman, R.J., Veerkamp, R. (2016). Harnessing the genetics of the modern dairy cow to continue improvements in feed efficiency. Journal of Dairy Science, 99(6), 4941-4954. doi: 10.3168/jds.2015-10352.

Yudin, V.M., Ljubimov, A.I., \& Nikitin, K.P. (2016). Selekcijia cherno-pestroj porody krupnogo rogatogo skota s ispol'zovaniem razlichnyh metodov plemennogo podbora. Izvestija Samarskoj gosudarstvennoj sel'skohozjaistvtnnoj akademii, I, 37-40. doi: 10.12737/18326 (in Russian). 